\title{
THE INFLUENCE OF OVIDUCAL FLUID ON THE DEVELOPMENT OF ONE-CELL RABBIT EMBRYOS IN VITRO*
}

\author{
J. W. KILLE $\dagger$ AND G. E. HAMNER \\ Department of Biology and Department of Obstetrics and Gynecology, \\ University of Virginia, Charlottesville, Virginia 22903, U.S.A.
}

(Received 26th September 1972)

\begin{abstract}
Summary. Daily oviducal fluid samples were collected from rabbits for 3 days before and 21 days after ovulation. Pronuclear rabbit embryos collected $15 \frac{1}{2} \mathrm{hr}$ after an ovulatory injection of HCG were cultured in drops of oviducal fluid under paraffin oil for 1 to 9 days to determine whether the fluid would support normal cleavage and expansion of the blastocyst.

In oestrous fluid, optimal development was at the four-cell stage and only $8 \%$ of the dividing embryos attained the expanded blastocyst stage. In 8 -day oviducal fluid, $88 \%$ became expanding blastocysts, frequently to diameters of $3 \mathrm{~mm}$ or more. In fluid from the 13th day of pseudopregnancy to the end of the cycle, embryo development was no better than in oestrous fluid.

It is suggested that a component of oviducal fluid, particularly active on Day 2 and Days 8 and 9 after ovulation, significantly enhances the developmental capacity of the preimplantation rabbit embryo. The component(s) is heat labile at $60^{\circ} \mathrm{C}$ but is stable for at least 9 days when stored at $4^{\circ} \mathrm{C}$. This activity is not dependent on the presence of ova in the oviducts, nor does it require interaction of the fluid component(s) with the formed mucin coat of the embryo.
\end{abstract}

\section{INTRODUCTION}

Throughout the reproductive cycle, the oviduct produces a considerable amount of fluid which varies both quantitatively and qualitatively during periods when critical developmental events are taking place in the embryo (Mastroianni, Urzua, Avalos \& Stambaugh, 1969; Restall, 1966; Hamner \& Fox, 1969).

Explanted mouse oviduct ampullae in culture will support development of mouse zygotes to the blastocyst stage (Gwatkin \& Biggers, 1963; Whittingham, $1968 \mathrm{a}, \mathrm{b})$, and oviducts explanted at metoestrus will support development of more zygotes than will oviducts from dioestrous mice (Whittingham, 1968b).

\footnotetext{
* A preliminary report of this study was presented at the Fourth Annual Meeting of the Society for the Study of Reproduction, Boston, Massachusetts, 1971.

$\dagger$ Present address: Animal Research Station, 307 Huntingdon Road, Cambridge CB3 0JQ.
} 
Thus, a functional change over the cycle in the ability of explanted ampullae to support development of mouse zygotes has been demonstrated. More specifically, mucin, a substance secreted by the oviducts of rabbits and some other mammals, may play an important, but as yet undefined, rôle in the development or implantation of the early embryo (Greenwald, 1958, 1962, 1969; Adams, 1960).

This series of experiments was designed to test whether rabbit oviducal fluid would support development of the preimplantation embryo and, if so, whether its effect on development would change during the course of pseudopregnancy.

\section{MATERIALS AND METHODS}

Mature virgin New Zealand White female rabbits, weighing 3.5 to $4.0 \mathrm{~kg}$, and New Zealand males of proven fertility were the donors of eggs and spermatozoa for this series of experiments. Larger $(5 \mathrm{~kg})$, post-partum, reproductively active, New Zealand females were chosen to supply oviducal fluid. Each rabbit was caged individually and allowed free access to water and Purina rabbit chow.

Oviducal fluid was collected daily by means of a glass flask especially designed for this purpose by Hamner \& Williams (1965), which was surgically placed into oestrous donors. Following a recovery period of 1 to 2 days, fluid was collected for 2 more days after which the fluid donor was induced to ovulate with an injection of 50 i.u. HCG (Follutein, E. R. Squibb \& Sons). The fluid collected the next day (and each day for the next 20 days) was regarded as Day 1 (to Day 20) pseudopregnancy fluid. Immediately after collection, the fluid was centrifuged at $1500 \mathrm{~g}$ for $5 \mathrm{~min}$ to remove any epithelial débris. Phenol red was added as a $\mathrm{pH}$ indicator, and the fluid was stored at $4^{\circ} \mathrm{C}$ in sealed sterile Pyrex tubes.

Fertilized ova were obtained by artificial insemination of New Zealand virgin does induced to ovulate with 50 i.u. HCG. To eliminate the possibility that the mucin coat of the rabbit egg was providing some beneficial material to the embryo, the fertilized ova were removed before acquiring any mucin. To accomplish this, the donors' oviducts were excised $15 \frac{1}{2}$ to $15 \frac{3}{4} \mathrm{hr}$ after the injection of HCG and the eggs were flushed out under sterile gas-equilibrated oil. Brinster's (1970) KRBF medium with increased sodium bicarbonate (Stambaugh, Noriega \& Mastroianni, 1969) and an equimolar decrease in $\mathrm{NaCl}$ was used as the flushing medium. This specific timing allowed recovery of fertilized ova with the cumulus naturally dispersed, but with no mucin coat as this begins to accumulate around the ova about $16 \mathrm{hr}$ after the injection of HCG.

These one-cell pronuclear embryos were transferred with a minimal amount of flushing medium to $0.5 \mathrm{ml}$ oviducal fluid which was to be used for medium, and were cultured in $75 \mu \mathrm{l}$ of the fluid placed under light, sterile, gas-equilibrated paraffin oil in an atmosphere of $8 \% \mathrm{O}_{2}, 5 \% \mathrm{CO}_{2}$ and $87 \% \mathrm{~N}_{2}$ (see Whitten, 1956; Daniel, 1968) for 1 to 9 days without changing the medium. Cultures were examined daily by light microscopy for normally dividing embryos, expansion of the blastocyst, and formation of an inner cell mass. All embryos scored as 'zona-free blastocysts' possessed a well-defined inner cell mass, i.e. blastocoelic vesicles without an inner cell mass were not regarded as 
zona-free blastocysts even if they were completely detached from the zona pellucida.

\section{RESULTS}

In Table 1, the results of culturing pronuclear rabbit embryos in oestrous and postovulatory oviducal fluid are represented as the percentage of those eggs dividing which developed to the late morula stage throughout the various media, and the percentage which developed to the expanded blastocyst. Since serum is believed to contribute to the composition of oviducal fluid by transudation, $100 \%$ rabbit serum which was heated at $56^{\circ} \mathrm{C}$ for $30 \mathrm{~min}$ was used for the control medium (HBS).

Table 1. Percentages of dividing embryos attaining late morula and expanding blastocyst stages in oviducal fluid

\begin{tabular}{l|c|c}
\hline & $\begin{array}{c}\% \text { late } \\
\text { morula }\end{array}$ & $\begin{array}{c}\text { \% expanding } \\
\text { blastocysts }\end{array}$ \\
\hline HBS control & 79 & 22 \\
Oestrous O.F. & 41 & 8 \\
1 day psp & 51 & 22 \\
2 day psp & 69 & 62 \\
3 to 4 day psp & 84 & 40 \\
5 to 6 day psp & 61 & 54 \\
7 day psp & 46 & 28 \\
8 day psp & 94 & 88 \\
9 day psp & 88 & 81 \\
10 to 12 day psp & 52 & 31 \\
13 to 15 day psp & 36 & 23 \\
16 to 18 day psp & 50 & 31 \\
19 to 21 day psp & 38 & 19 \\
& $P<0.01$ & \\
\hline
\end{tabular}

HBS, heat-treated rabbit serum; O.F., oviducal fluid; psp, pseudopregnancy fluid.

These percentages were based on one-celled embryos which, when cultured in the indicated media, divided and continued development to the early morula or expanding blastocyst stages. The distribution of late morulae attained in all culture media is significantly different from the distribution of expanding blastocysts as determined by the Rank Test for non-parametric data described by Goldstein (1961).

Marked differences were apparent in the ability of the embryo both to grow to the morula stage and to continue to the expanding blastocyst stage, and in the proportions of eggs reaching these stages in the various fluids of the pseudopregnancy cycle. Most embryos (79\%) readily developed to the morula stage (see Pl. 1, Figs 1 to 8 , for a description of typical stages observed in this study) in HBS but little more than $25 \%$ of those continued to the expanding blastocyst. In oestrous oviducal fluid, only $41 \%$ achieved the morula stage and $20 \%$ of those continued to the expanding blastocyst. In postovulatory or pseudopregnancy fluid, there seems to be a bimodal effect both in the percentage of morulae attained and in the proportion of those morulae which continued development. 


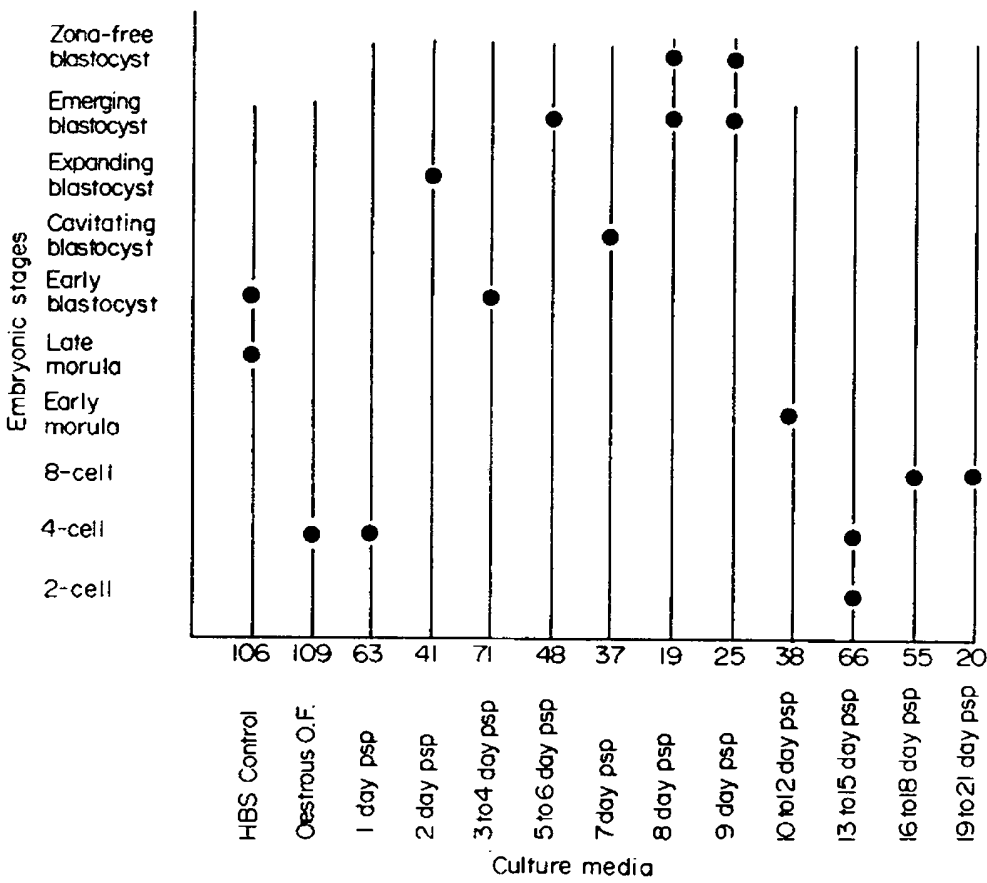

Texr-Fig. 1. Embryonic development in oviducal fluid (O.F.) in vitro. One-cell rabbit embryos were cultured in heated serum (HBS) or in rabbit oviducal fluid collected from pseudopregnant (psp) rabbits on the days indicated. The vertical bars represent the maximal developmental stage (or range of development) and the blackened circles indicate the optimal developmental stage attained in each medium. The number of onecell embryos cultured in each category is indicated beneath the abscissa.

\section{EXPLANATION OF PLATE 1}

Figs 1 to 8 . Description of stages observed in culture. All embryos were photographed directly from the culture dish without fixing or staining and were replaced in the controlled environment immediately afterwards. Except where indicated, photomicroscopy was accomplished with normal light optics and bright field.

Fic. 1. One-cell rabbit embryo. All cultures began with this stage. Note the polar bodies (arrow) and absence of the mucin coat peripheral to the zona pellucida $(\mathrm{Z}), \times 250$ (phase contrast).

Fig. 2. Typical four-cell embryo. Self explanatory, as is the eight-cell stage. An embryo of approximately sixteen cells was considered an early morula. $\times 125$.

FIG. 3. Late morula: contains more than sixteen cells but its overall size is no greater than the early morula. The zona pellucida has not yet begun to stretch. $\times 250$.

Fig. 4. Cavitating blastocyst: larger overall, with a correspondingly thinner zona pellucida. The blastocoelic cavity is becoming evident on the left. $\times 125$.

Fig. 5. Expanding blastocyst: slightly larger than the cavitating blastocyst with a thin zona pellucida, well defined blastocoelic cavity (b) and inner cell mass (i); single celllayer trophoblast. $\times 125$.

Fig. 6. Emerging blastocyst: the zona pellucida ruptures and the blastocyst begins to escape from it. There is no coat of mucin to confine the emerging portion. $\times 125$.

Fig. 7. Zona-free blastocyst: here the blastocyst has completely emerged from the zona pellucida. Note the empty zona (arrow). This stage requires approximately 6 to 8 days in culture. $\times 50$.

Frc. 8. Zona-free blastocyst: after the blastocyst becomes free of the zona, it continues to expand and frequently attains diameters of 3 to $4 \mathrm{~mm} . \times 50$. 


\section{PIATE 1}
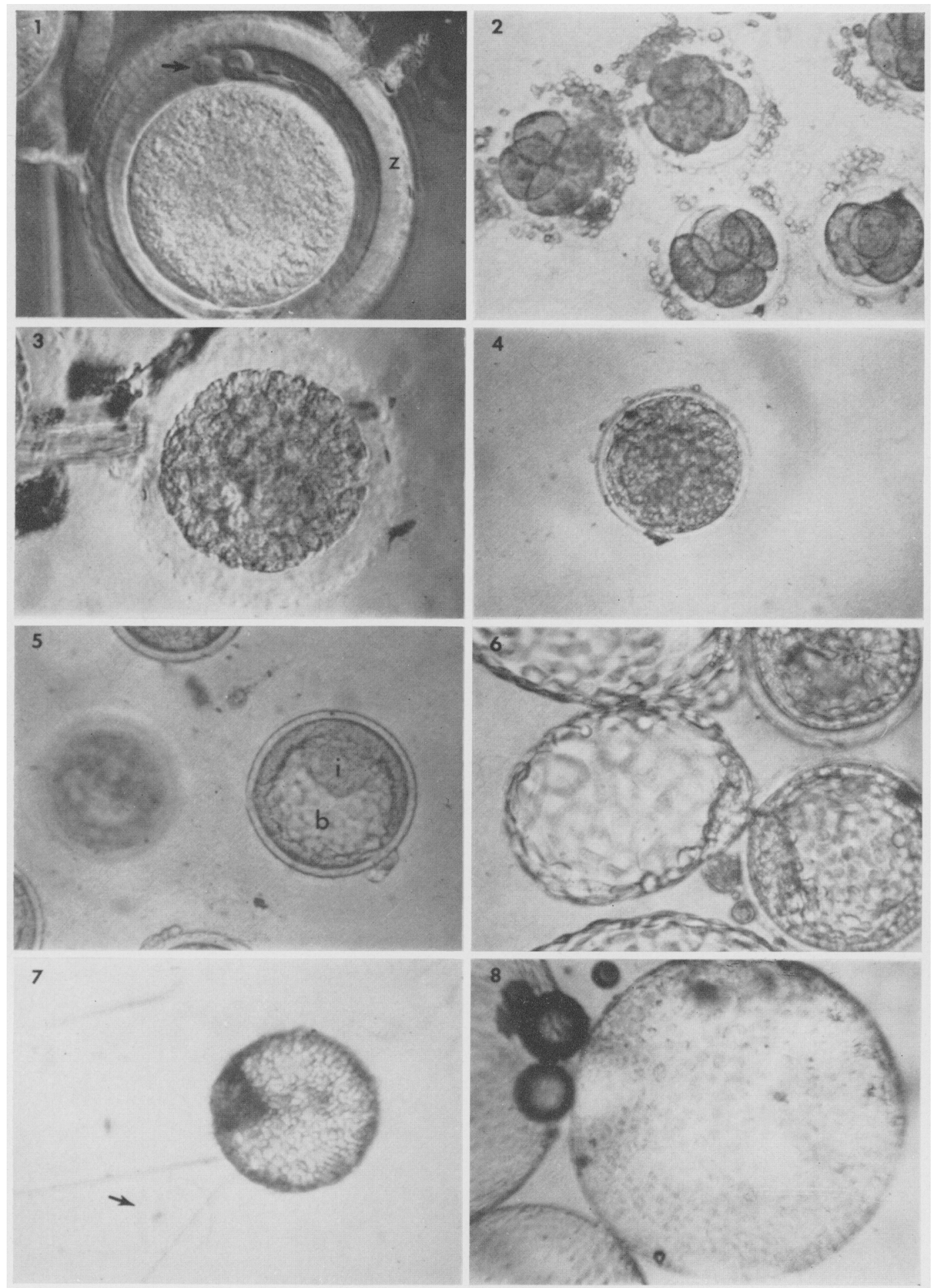

(Facing p. 418) 
The most positive effect was noted in fluid from Day 2 and Days 8 and 9 after ovulation. The ability of fluid from the end of the cycle (Days 13 to 21) to support embryonic development was no better than that of oestrous fluid.

In order to obtain some estimate of the optimal development in each category of oviducal fluid, all the data from cultures were entered into a contingency table and that developmental stage in each medium which made the greatest contribution to the overall Chi Square $(P<0.001)$ was taken as an approximation of the optimal development in that medium (Text-fig. 1).

While optimal development in HBS was at the late morula and early blastocyst stages, that in oestrous and Day-1 pseudopregnancy fluid occurred much earlier, namely the four-cell stage. Growth in 2-day fluid was also greatly different from that in HBS and especially oestrous fluid, but in the positive

Table 2. Optimum development of rabbit embryos in oviducal fluid compared with controls

\begin{tabular}{|c|c|c|}
\hline & $\underset{\mathrm{P}}{H B S \text { control }}$ & $\underset{\mathbf{P}}{\text { Oestrous }}$ O.F. \\
\hline $\begin{array}{l}\text { HBS control } \\
\text { Oestrous O.F. } \\
1 \text { day psp } \\
2 \text { day psp } \\
3 \text { to } 4 \text { day psp } \\
5 \text { to } 6 \text { day psp } \\
7 \text { day psp } \\
8 \text { day psp } \\
9 \text { day psp } \\
10 \text { to } 12 \text { day psp } \\
13 \text { to } 15 \text { day psp } \\
16 \text { to } 18 \text { day psp } \\
19 \text { to } 21 \text { day psp }\end{array}$ & $\begin{array}{l}<\overline{0.001} \\
<0.05 \\
<0.001 \\
<0.05 \\
<0.01 \\
\text { N.S. } \\
<0.001 \\
<0.001 \\
\text { N.S. } \\
<0.001 \\
<0.01 \\
<0.01\end{array}$ & $\begin{array}{l}\quad \bar{z} \\
\text { N.S. } \\
\ll 0.001 \\
<0.001 \\
<0.001 \\
<0.01 \\
\ll 0.001 \\
\ll 0.001 \\
<0.001 \\
\text { N.S. } \\
\text { N.S. } \\
\text { N.S. }\end{array}$ \\
\hline
\end{tabular}

HBS, heat-treated rabbit serum; O.F., oviducal fluid; psp, pseudopregnancy fluid.

Levels of significance were determined from the raw data by the Chi Square Test for the optimal developmental stage (see Text-fig. 1) in each fluid category compared with the appropriate control. The symbol $\ll$ indicates a $\chi^{2}$ value greater than 25 where $P \leqslant 0.001 \geqslant 10.827$. The values in italic type were significantly below controls; N.S. $=$ no significant difference.

direction, the expanding blastocyst being optimally attained here. In fluids collected between Days 3 and 7 after ovulation, development was variable but generally greater than that in HBS alone. In the fluid from 8 and 9 days after ovulation, optimal development was established at the emerging and completely zona-free blastocyst stages. Development supported by 10- to 12-day fluid, however, was significantly reduced to serum levels, and in fluid from the 13th day after ovulation to the end of the cycle, optimal levels were further reduced to that found in oestrous oviducal fluid. Since pseudopregnancy usually lasts about 17 days, the secretions from the latter part of that period may take on the character of the oestrous condition. 
Individual Chi Squares were subsequently computed from the raw data. Table 2 shows the comparison of the various optimal values in pseudopregnancy fluid with those of HBS or oestrous fluid.

The positive activity of oviducal fluid was stable for at least 9 days when stored at $4^{\circ} \mathrm{C}$. In two cultures, however, eighteen eggs were placed in aliquots of Day-8 pseudopregnancy oviducal fluid which were previously heated in tightly sealed tubes to $60^{\circ} \mathrm{C}$ and $100^{\circ} \mathrm{C}$ for $10 \mathrm{~min}$. In the sample of six eggs heated to $60^{\circ} \mathrm{C}$, none cleaved. Of twelve ova cultured in fluid heated to $100^{\circ} \mathrm{C}$, one was at the eight-cell, one at the six-cell, and two were at the twocell stage and eight ova were undivided after $24 \mathrm{hr}$. Apparently, the eight-cell and six-cell stages were fragmented ova and not true cleavage divisions. No further cleavages occurred over the next 2 days in either group.

\section{DISGUSSION}

Pyruvate and lactate have been shown to be beneficial to the rabbit embryo during the first few cleavages in vitro (Daniel, 1967; Brinster, 1970; Kane \& Foote, 1971) and the cumulus cells provide the early embryo with pyruvate in situ (Donahue \& Stern, 1968). Neither pyruvate nor lactate alone will support early rabbit development, however, but an amino nitrogen source such as oxidized glutathione will (Brinster, 1970). Certain free amino acids are also thought to be essential (Daniel \& Olson, 1968; Brinster, 1970). These cultures began with two- to four-cell embryos and continued to the morula and blastocyst stages. In the experiments of Onuma, Maurer \& Foote (1968), 74\% of the blastocysts expanded and escaped from their zonae in bovine serum with pronase added (diameter $\leqslant 361 \mu \mathrm{m}$ ).

More recently, Kane \& Foote (1971) were able to culture one-cell rabbit embryos in a defined medium in which $48 \%$ became expanded blastocysts and $1 \%$ ruptured the zona (these expanded to over $300 \mu \mathrm{m}$ in diameter). Ogawa, Satoh \& Hashimoto (1971) were also able to culture one-cell embryos in a different defined medium and achieve $56 \%$ expanding blastocysts (no measurements given) but without the zona-rupturing phenomenon.

In the present experiments, the intent was not to approximate the natural environment of the embryo by supplying it with a synthetic medium, but rather to examine its patterns of growth and development in an in-vitro system, utilizing the actual fluid supplied by the oviduct. This fluid comprises the total environment of the embryo during the first 3 days after ovulation when the embryo is in the oviduct, and may also contribute to the uterine environment (Bishop, 1956; Bellvé \& McDonald, 1968; Greenwald, 1969).

Our results show that oviducal fluid can support growth and development of the preimplantation rabbit embryo, though oviducal fluid collected on various days after ovulation does not support embryonic development to the same degree throughout the course of early gestation. This is not surprising since the reproductive tract environment, its secretions and the embryo's requirements are constantly changing. What is interesting in this respect is that 8- and 9-day oviducal fluids (some of the most active fluids in terms of in-vitro embryonic development) arise at a time when (a) there is a corresponding rise in oestrogen 
output from the ovary (Hilliard \& Eaton, 1971), and (b) the embryo is already in the uterus.

Kay \& Feigelson (1972) have demonstrated the presence of a non-serum oviducal protein in the rabbit which is detectable only under the influence of oestrogen. Whether this protein exhibits any biological activity with respect to embryonic development is not yet known. Blastocyst development can, however, proceed in the uterus isolated from the oviduct at $3 \frac{1}{2}$ days after ovulation, which implies that tubal secretions arising after that time may not be essential to embryonic development (Hafez, 1963).

It should be noted that collecting oviducal fluid with a ligature at one end of the oviduct and a cannula in the other introduces unnatural constrictions on the tube which may affect the fluid with respect to composition and/or quantity. It seems unlikely, however, that the daily variations we have observed in these experiments could be due to the chronic effects of an indwelling cannula. The only other method of collecting fluid which would avoid the ligation and cannulation would be that of flushing the tubes. This would be unsatisfactory both for use of the oviducal flushings as direct culture media, and in view of the number of rabbits required to obtain daily samples. We do know from this work that rabbit embryos will cleave normally in oviducal fluid collected in the flask. If any changes occur due to this method, they must therefore be subtle and do not appear to be detrimental to the embryo.

In the rabbit, it is generally accepted that the zona pellucida does not rupture but remains intact up to the time of implantation. Ruptures of rabbit zonae pellucidae noted in culture have been called herniations and have sometimes been considered indicative of abnormal development or at least regarded as non-physiological phenomena. In species where loss of the zona some time before implantation is usual, the question has been raised as to whether it is lost by mechanical means or chemical, i.e. dissolution of the zona. Certainly, a considerable force must be exerted on the zona by the rapidly expanding rabbit blastocyst, and given the ultimate size attained by the blastocyst, one would expect the zona to rupture. Instead, it appears to stretch and become thinner as the blastocyst expands. One might speculate that the zona is either rendered more rigid due to some condition of in-vitro culture with subsequent rupture, or becomes more elastic in the uterus, allowing it to stretch as the blastocyst increases in size. Oviducal fluid should more closely approximate the natural environment than any synthetic medium, and yet the zona ruptures in this fluid as well. It seems more probable, therefore, that some factor incumbent on the blastocyst in the uterus promotes stretching of the zona pellucida. Kirchner (1972) has demonstrated the presence of at least two proteolytic enzymes in the rabbit uterus which are active on the 'blastocyst covering'. These enzymes are evidently absent or inactive in oviducal fluid. This does not preclude normal division and development of the cells of the blastocyst (indeed, a prerequisite for scoring embryos as expanded zona-free blastocysts was the presence of an embryonic disc).

Expansion of the rabbit blastocyst in culture may simply reflect changes in osmolarity in the various culture media, rather than changes in biological activity. In the present experiments, all embryos were cultured from the one- 
cell stage, so 'expanded blastocyst' here denotes not only increased diameter of the embryo but also the achievement of the cleavage and differentiation leading from the one-cell to the normal blastocyst stages.

Since, in this fluid-collecting system, no ova can enter the oviducts of fluid donors, it may be concluded that no direct causal relationship exists between the presence of embryos in the oviduct and the oviduct's ability to support embryonic development. But the following observations, (a) that in preliminary experiments, the addition of pyruvate to oestrous oviducal fluid does not increase the growth-supporting potential of that fluid, (b) that oviducal fluid from certain days of the cycle supports embryo development to a greater extent than serum alone, and (c) that heating 8-day fluid drastically reduces its culture capabilities, indicate that we are dealing with a non-serum macromolecular factor which is secreted and probably synthesized by the oviduct, does not require the presence of the mucin coat and has a specific positive effect (rather than a general nutritive one) on the development of the preimplanted rabbit embryo.

\section{ACKNOWLEDGMENTS}

This work was supported by U.S. Public Health Service Grant HD-06573 and Research Career Development award HD-12760 (to G.E.H.) from the National Institute of Child Health and Human Development.

We thank Miss Margaret Wells and Mrs Ann E. Malek for their excellent technical assistance.

\section{REFERENCES}

Adams, C. E. (1960) Development of the rabbit egg with special reference to the mucin layer. In: 1st Int. Congr. Endocr., Abstr. No. 345, p. 687.

Bellvk, A. R. \& McDonald, M. F. (1968) Directional flow of Fallopian tube secretion in the Romney ewe. 7. Reprod. Fert. 15, 357.

Bishop, D. W. (1956) Active secretion in the rabbit oviduct. Am. F. Physiol. 187, 347.

Brinster, R. L. (1970) Culture of two-cell rabbit embryos to morulae. F. Reprod. Fert. 21, 17.

DANIEL, J. C. (1967) The pattern of utilization of respiratory metabolic intermediates by preimplantation rabbit embryos. Expl Cell Res. 47, 619.

DanIEL, J. C., JR (1968) Oxygen concentrations for culture of rabbit blastocysts. F. Reprod. Fert. 17, 187.

DANIEL, J. C., JR \& Olson, J. D. (1968) Amino acid requirements for cleavage of the rabbit ovum. 7 . Reprod. Fert. 15, 453.

Donahue, R. P. \& StERn, S. (1968) Follicular cell support of oocyte maturation: production of pyruvate in vitro. F. Reprod. Fert. 17, 395.

Goldstern, A. (1961) Biostatistics, an introductory text, p. 115. Macmillan, New York.

Greenwald, G. S. (1958) Endocrine regulation of the secretion of mucin in the tubal epithelium of the rabbit. Anat. Rec. 130, 477.

Greenwald, G. S. (1962) The role of the mucin layer in development of the rabbit blastocyst. Anat. Rec. $142,407$.

Greenwald, G. S. (1969) Endocrinology of oviductal secretions. In: The Mammalian Oviduct, p. 183. Eds. E. S. E. Hafez and R. J. Blandau. University of Chicago Press, Chicago.

Gwatkin, R. B. L. \& Biggers, J. D. (1963) Histology of mouse Fallopian tubes maintained as organ cultures on a chemically defined medium. Int. F. Fert. 8, 543.

HAFEZ, E. S. E. (1963) Gestation in salpingectomized-ovariectomized progesterone-treated rabbits. Proc. Soc. exp. Biol. Med. 114, 604.

HAMNer, C. E. \& Fox, S. B. (1969) Biochemistry of oviductal secretions. In: The Mammalian Oviduct, p. 333. Eds. E. S. E. Hafez and R. J. Blandau. University of Chicago Press, Chicago.

Hamner, C. E. \& Williams, W. L. (1965) Composition of rabbit oviductal secretions. Fert. Steril. 16, 170 .

Hilliard, J. \& Eaton, L. W. (1971) Estradiol-17 $\beta$, progesterone and 20 $\alpha$-hydroxypregn-4-en-3-one in rabbit ovarian venous plasma. II. From mating through implantation. Endocrinology, 89, 522. 
KANE, M. T. \& Foote, R. J. (1971) Factors affecting blastocyst expansion of rabbit zygotes and young embryos in defined media. Biol. Reprod. 4, 41.

KAy, E. \& FeIgelson, M. (1972) An estrogen modulated protein in rabbit oviductal fluid. Biochim. biophys. Acta, 271, 436.

KIRCHNER, C. (1972) Uterine protease activities and lysis of the blastocyst covering in the rabbit. $\mathcal{F}$. Embryol. exp. Morph. 28, 177.

Mastrolanni, L., Jr, Urzua, M. A., Avalos, M. \& Stambaugh, R. (1969) Some observations on Fallopian tube fluid in the monkey. Am. F. Obstet. Gynec. 103, 703.

Ogawa, S., Satoh, K. \& Hashimoto, H. (1971) In vitro culture of rabbit ova from the single cell to the blastocyst stage. Nature, Lond. 233, 422.

Onuma, H., Maurer, R. R. \& Foote, R. H. (1968) In-vitro culture of rabbit ova from early cleavage stages to the blastocyst stage. F. Reprod. Fert. 16, 491.

Restalc, B. J. (1966) The Fallopian tube of the sheep. 2. The influence of progesterone and oestrogen on the secretory activities of the Fallopian tube. Aust. F. biol. Sci. 19, 187.

Stambaugh, R., Noriega, G. \& Mastrotanni, L., JR (1969) Bicarbonate ion; the corona cell dispersing factor of rabbit tubal fluid. F. Reprod. Fert. 18, 51.

Whitren, W. K. (1956) Culture of tubal mouse ova. Nature, Lond. 176, 96.

Whittingham, D. G. (1968a) Development of zygotes in cultured mouse oviducts. 1. The effect of varying oviductal conditions. F. exp. Zool. 169, 391 .

Whittingham, D. G. (1968b) Development of zygotes in cultured mouse oviducts. 2. The influence of the estrous cycle and ovarian hormones upon the development of the zygote. F. exp. Zool. 169, 399. 